\title{
ANALISIS KONSISTENSI PERENCANAAN DAN PENGANGGARAN DI KABUPATEN PEGUNUNGAN BINTANGSTUDI KASUS PADA DINAS PERHUBUNGAN, KOMUNIKASI DAN INFORMATIKA TAHUN 2013-2015
}

\author{
Alferus Sanuari ${ }^{1}$ \\ jurnalmkd@gmail.com \\ Yundhy Hafizrianda \\ hariman.andalan@gmail.com \\ Siti Rofingatun \\ sitiro@yahoo.com
}

\begin{abstract}
This research entitled Analysis of Planning and Budgeting Conceptency in Pegunungan Bintang District Case Study On Department of Transportation, Communication and Informatics Year 2013-2015. In this research try to analyze consistency between planning and budgeting seen from planning and budgeting document like RKPD, PPAS, and APBD. RKPD (Local Government Work Plan), which is the result of the selection of community aspirations through the Development Planning Council (Musrenbang). Furthermore, RKPD work plan and funding are used as guidance in the budgeting process (budgeting).

Budgeting begins with the preparation of Temporary Budget Priorities and Ceiling (PPAS). The approved PPAS is used as a guideline for the preparation of Regional Revenue and Expenditure Budget Plans (RAPBD) which is then ratified into Regional Revenue and Expenditure Budget (APBD). The results of the analysis are then analyzed using the Planning and Budgeting Consolidation Matrix to see how far the consistency is occurring.

The results of this study indicate that the average level of consistency planning and budgeting in the field of Transportation, Communications and Informatics in Pegunungan Bintang District in 2013-2015 is quite good where the average level of consistency of programs between RKPD and PPAS ranges between $80.00 \%$. While the average level of consistency of activities is $61.98 \%$.

This indicates that the drafting of the plan on PPAS still exists that is not guided by RKPD. The level of program consistency between PPAS and APBD has an average value of $60.64 \%$. While the average level of consistency of activity is $63.19 \%$. The level of planning and budgeting concessions from year to year shows a fluctuating value. In consistency the budget outline has a consistent value. Inconsistencies occur because there are activities that suddenly appear and are not contained in the previous document. This is due to delays in information activities from the central government.
\end{abstract}

Keywords: Consistency, Planning, Budgeting

\section{PENDAHULUAN}

Penganggaran diawali dengan penyusunan PPAS (Prioritas dan Plafon Anggaran Sementara) setelah diketahui informasi berapa ketersediaan anggaran. PPAS berfungsi sebagai dokumen untuk pembicaraan pendahuluan APBD yang menjembatani antara perencanaan (RKPD) dengan kebijakan dan rancangan anggaran berdasar pada ketersediaan atau pagu anggaran. Kemudian PPAS yang

\footnotetext{
${ }^{1}$ Alumni Mahasuswa Magister Keuangan Daerah Universitas Cenderawasih

2 Staf Dosen Jurusan IImu Ekonomi Fakultas Ekonomi \& Bisnis Universitas Cenderawasih

${ }^{3}$ Staf Dosen Jurusan Akuntansi Fakultas Ekonomi \& Bisnis Universitas Cenderawasih
} 
telah disepakati dijadikan pedoman untuk menyusun RAPBD yang kemudian disahkan menjadi APBD.

Masing-masing dinas dan instansi cenderung mengatakan tugas dan fungsinyalah yang terpenting dalam kegiatan pembangunan. Permasalahan tersebut menyebabkan koordinasi dalam penyusunan rencana dan pelaksanaan pembangunan menjadi sulit dilakukan. Akibat selanjutnya adalah kurang optimalnya pelaksanaan proses pembangunan dan bahkan sasaran yang dituju dapat tidak terlaksana sama sekali.

Aparat pemerintah daerah merupakan pelayan masyarakat yang harus mampu menerjemahkan dan mengimplementasikan berbagai aturan-aturan yang berlaku secara komprehensif dan konsisten serta mampu memfasilitasi masyarakat atas segala kebutuhan riilnya. Aparat pemerintah daerah harus mampu bersinergi dengan komponen stakeholder lainnya seperti masyarakat dan pelaku bisnis dan menjaga konsistensi dan disiplin perencanaan dan penganggaran. Salah satu wujud respon pemerintah daerah terkait dengan ini adalah lahirnya produk dokumen-dokumen perencanaan dan penganggaran seperti RPJMD, RKPD, RENSTRA SKPD, RENJA-SKPD, RKA, KUA/PPAS, dan RAPBD/APBD.

Ketersediaan dokumen-dokumen perencanaan dan penganggaran pemerintah daerah patut diapreasi, namun belum cukup untuk menjamin tercapainya efisiensi dan efektivitas penyelenggaraan otonomi daerah. Ada tiga hal pokok yang harus tetap dijaga didalam dokumen perencanaan dan penganggaran daerah: (i) konsistensi isi/muatan dalam satu dokumen dan konsistensi antar dokumen perencanaan dan penganggaran; (ii) penetapan indikator kinerja output dan outcome secara tepat dan konsisten; (iii) bentuk kreasi (kreativitas) pemerintah daerah dalam menjaga konsistensi perencanaan dan penganggaran. Ketiga hal pokok tersebut masih merupakan permasalahan utama bagi pemerintah daerah.

Konsistensi antar dokumen perencanaan dan penganggaran penting diperhatikan karena merupakan indikator dalam menilai kinerja pemerintah daerah. Hal ini sangat berpengaruh terhadap capaian dari visi, misi, tujuan, sasaran dan kebijakan yang telah direncanakan dalam dokumen perencanaan serta memiliki peran yang penting dalam pelaksanaan pembangunan untuk memperbaiki kesejahteraan masyarakat melalui program-program yang bertujuan untuk meningkatkan kualitas sumberdaya manusia, seperti pendidikan dan kesehatan. Menyadari pentingnya peran pemerintah daerah dalam proses pencapaian tujuan pembangunan, maka perlu disiapkan dengan baik perencanaan 
dan penganggarannya, sehingga semua dokumen perencanaan dan penganggaran di daerah harus dijaga konsistensinya.

Rencana Kerja Pemerintah Daerah sebagai dokumen perencanaan tahunan daerah yang memuat program dan kegiatan dari seluruh SKPD selanjutnya diintegrasikan kedalam proses penganggaran daerah melalui beberapa tahapan, mulai dari penyusunan Kebijakan Umum APBD, Prioritas dan Palafon Anggaran, Penyusunan Rencana Kerja Anggaran Satuan Kerja Perangkat Daerah (RKA SKPD) dan Penyusunan Lampiran-lampiran Perda APBD.

Aidinil Zetra (2008) menemukan bahwa kebanyakan SKPD telah menyusun renstra dan rencana kerja 1 tahun, akan tetapi banyak ditemukan dokumen renstra dan renja SKPD tersebut masih bersifat formalitas dengan rumusan sasaran, penetapan indikator serta target belum memuaskan. Penyusuan rencana kerja SKPD masih terjebak ke dalam pola lama penyusunan program yaitu mengajukan program sebanyak-banyaknya, dibuat seindah indahnya dan kadang-kadang tidak didasarkan kepada informasi tentang ketersediaan sumberdaya daerah dan arah pembangunan nasional. Selain itu terdapat banyak rencana kerja yang tumpang tindih baik antar SKPD maupun antara Propinsi dengan Kab Kota dan persoalan tarik-menarik kepentingan sektoral meskipun tidak mendukung pencapaian perumusan strategis (visi, misi dan tujuan) dan perencanaan strategik serta jauh dari skala prioritas daerah.

Kabupaten Pegunungan Bintang merupakan salah satu Kabupaten di wilayah Pegunungan Tengah hasil pemekaran dari Kabupaten Jayawiya yang di bentuk pada tanggal 21 Nopember 2002 dengan Undang-undang Nomor 26 Tahun 2002. Sebagai daerah otonom baru yang definitf pada tahun 2005, Pemerintah kabupaten Pegunungan Bintang berupaya menyusun dokumen perencanaan sebagai arah dan kebijakan dalam peyusunan anggaran daerah.

Pada tahun 2011 melalui Peraturan Bupati Nomor 13 Tahun 2011 telah disusun Dokumen Perencanaan Menengah Daerah (RPJMD Kabupaten Pegunungan Bintang Tahun 2011-2015 sebagai acuan/arah dalam penyusunan program selama 5 (lima) tahun.

Dalam pelaksanaan Peraturan Bupati (PERBUB) Pegunungan Bintang Nomor 13 tahun 2011 tentang RPJMD Kabupaten Pegunungan Bintang Tahun 2011-2015 tentunya banyak kekurangan-kekurangan dalam implementasi PERBUP tersebut misalnya (1) kurangnya komitmen dalam pelaksanaan RPJMD, (2) Belum maksimalnya kinerja tim Anggaran Daerah (3) masih ada Satuan Kerja Perangkat Daerah yang belum menyusun Rencana Strategis ( RENSTRA - SKPD ), (4) kualitas dari RENSTRA yang disusun oleh SKPD yang sudah ada masih 
kurang memadai, (5) pemahaman tim anggaran di DPRD yang masih kurang tentang proses perencanaan dan penganggaran di Daerah. Dari hal - hal diatas menyebabkan terjadinya inkonsistensi pelaksanaan dokumen perencanaan dan penganggaran di Kabupaten Pegunungan Bintang.

Berdasarkan penjelasan di atas, maka penelitian ini bertujuan untuk mengevaluasi konsistensi antar dokumen perencanaan dan penganggaran, yakni muatan dan substansi RPJMD, RKPD, dan APBD pelaksanaannya dari sisi keselarasan program, kegiatan, dan anggaran khususnya pada SKPD Dinas Perhubungan, Komunikasi dan Informatika Kabupaten Pegunungan Bintang. Adapun tujuan yang ingin dicapai dalam penelitian ini adalah : (1) Untuk menganalisis bagaimana konsistensi antara Dokumen Perencanaan dan Penganggaran SKPD Dinas Perhubungan, Komunikasi dan Informatika terhadap Dokumen Perencanaan dan penganggaran Kabupaten Pegunungan Bintang; (2) Untuk menganalisis faktor-faktor penyebab inkonsistensi antar Dokumen Perencanaan dan penganggaran SKPD terhadap Dokumen Perencanaan dan penganggaran Kabupaten Pegunungan Bintang.

Menurut Arsyad (2002), menyebutkan 4 elemen dasar perencanaan yakni:

(1) Merencanakan berarti memilih; (2) Perencanaan merupakan alat pengalokasian sumber daya; (3) Perencanaan merupakan alat mencapai tujuan; (4) Perencanaan untuk masa depan. Banyak sekali definisi perencanaan yang dikemukakan oleh para ahli. Berikut ini adalah beberapa definisi perencanaan menurut Arthur W. Lewis (1965), Michael Todaro, George R. Terry (1960), Menurut D. Conyers dan Hill (1984), Menurut Syafrizal (2009), Menurut Jhingan (2000), Suhadak dan Trilaksono (2007) secara garis besar dapat disimpulkan bahwa perencanaan pada hakekatnya adalah sebuah hasil upaya (pengelola atau negara atau organisasi lainnya) dalam memutuskan strategi serta tindakan apa yang akan dilakukan untuk mencapai tujuan. Keputusan atas strategi yang diambil tidak bisa ditentukan sembarang melainkan setelah menganalisis kenyataankenyataan masa kini dan masa yang akan datang dengan pendekatan yang rasional dan dapat dipertanggungjawabkan menggunakan asusmsi yang relevan.

Sedangkan dalam UU No. 25 Tahun 2004 tentang Sistem Perencanaan Pembangunan Nasional (SPPN) pada pasal 1 ayat 2 menyebutkan bahwa perencanaan adalah suatu proses untuk menentukan tindakan masa depan yang tepat, melalui urutan pilihan, dengan memperhitungkan sumber daya yang tersedia.

Adam Smith dalam Mangkoesoebroto (2008) mengemukakan teori tentang fungsi pemerintah, yaitu: (1) Memelihara keamanan dalam negeri dan pertahanan; 
(2) Menyelenggarakan peradilan; (3) Menyediakan barang-barang yang tidak disediakan oleh pihak swasta. Sementara itu Prasetya, (2012) menjelaskan bahwa dalam melaksanakan fungsi-fungsi tersebut, pemerintah harus melakukan pengeluaran. Pengeluaran pemerintah merupakan biaya yang harus dikeluarkan oleh pemerintah untuk melaksanakan suatu kebijakan. Pengeluaran pemerintah dapat juga diartikan sebagai penggunaan uang dan sumber daya suatu negara/daerah untuk membiayai suatu kegiatan pemerintah dalamrangka mewujudkan fungsinya dalam melakukan kesejahteraan.

Perencanaan pembangunan nasional dan daerah diatur dengan UndangUndang Nomor 25 tahun 2004 tentang SPPN. Sistem perencanaan pembangunan nasional adalah satu kesatuan tatacara perencanaan pembangunan untuk menghasilkan rencana-rencana pembangunan dalam jangkapanjang, jangka menengah, dan tahunan yang dilaksanakan oleh unsur penyelenggara negara danmasyarakat di tingkat pusat dan daerah.

Perencanaan pembangunan daerah adalah suatu proses penyusunan tahapan-tahapan kegiatan yang melibatkan berbagai unsur pemangku kepentingan di dalamnya, guna pemanfaatan dan pengalokasian sumber daya yang ada dalam rangka meningkatkan kesejahteraan sosial dalam suatu lingkungan wilayah/daerah dalam jangka waktu tertentu (Peraturan Pemerintah Nomor 8Tahun 2008 tentang Tahapan, Tatacara Penyusunan, Pengendalian dan Evaluasi Pelaksanaan Rencana Pembangunan Daerah).

Peraturan Menteri Dalam Negeri Nomor 54 Tahun 2010 tentang Pelaksanaan Peraturan Pemerintah Nomor 8 Tahun 2008, menyebutkan bahwa perencanaan pembangunan daerah menggunakan pendekatan teknokratis, partisipatif, politis dan Top-Down danBottom-Up.

Berdasarkan kerangka teoritis diatas dan fenomena yang terjadi di daerah yaitu masih sering terjadi inkonsistensi antara dokumen perencanaan dan penganggaran yang menyebabkan sering tidak tercapainya tujuan dan sasaran pembangunan khususnya di bidang Perhubungan, Komunikasi dan Informatika. Untuk itu penelitian ini mencoba menjawab pertanyaan penelitian dengan menganalisis konsistensi program dan kegiatan pada dokumen perencanaan dan dokumen penganggaran dan faktor yang menyebabkan terjadinya inkonsistensi. Untuk itu maka dapat dideskripsikan dalam bagan berikut ini: 


\section{Gambar 1.1 Model Penelitian}

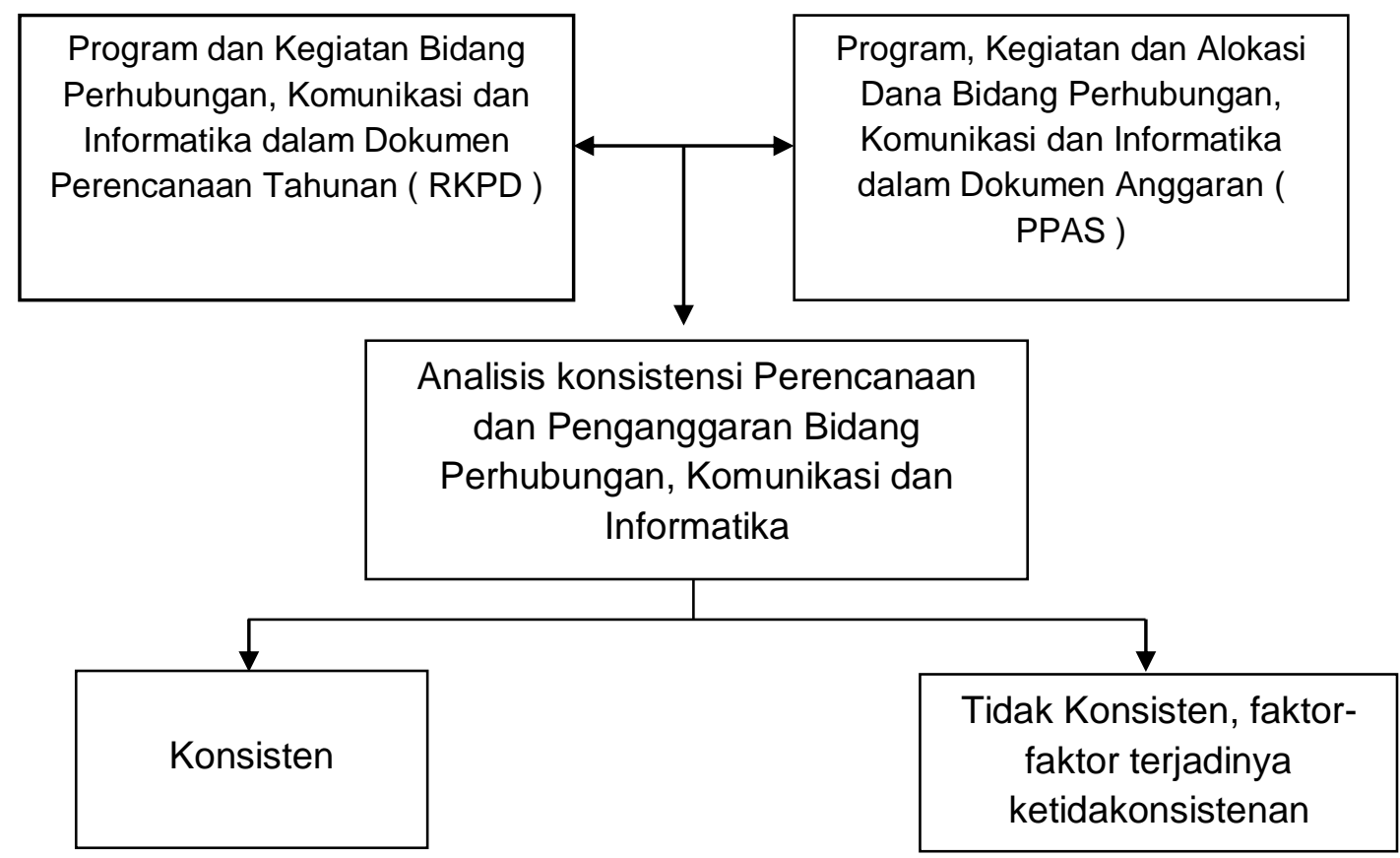

Sumber : Berbagai Sumber Penulis (2016)

\section{METODE PENELITIAN}

Dalam penelitian ini menggunakan pendekatan deskriptif kualitatif, melalui pendekatan ini penulis inggin mengukur konsistensi antara perencanaan dan penganggaran bidang perhubungan, komunikasi dan informatika untuk melihat seberapa besar implikasi antara program dan kegiatan pada dokumen perencanaan dan dokumen penganggaran. Sementara tujuan utamanya adalah menganalisis inkonsistensi antara dokumen perencanaan dan penganggaran SKPD terhadap Dokumen Perencanaan dan penganggaran Kabupaten Pegunungan Bintang. Selanjutnya tehnik pengumpulan data memakai studi pustaka dengan mempelajari dokumen yang memliliki keterkaitan langsung dengan perencanaan dan penganggaran.

\section{HASIL DAN PEMBAHASAN}

Analisis Konsistensi antara RKPD dan PPAS Bidang Perhubungan, Komunikasi dan Informatika Kabupaten Pegunungan Bintang tahun 20132015, Rencana Kerja Pemerintah Daeraha ( RKPD ) merupakan dokumen yang disusun sebelum Penentuan Plafon Anggaran Sementara ( PPAS ). Penyusunan Program dan kegiatan pada PPAS berpedoman pada RKPD. Analisis tingkat Konsistensi program dan kegiatan antara RKPD dan PPAS dimaksudkan untuk melihat bagaimana konsistensi PPAS terhadap program dan kegiatan yang ada 
pad RKPD. Semakin banyak program dan kegiatan di PPAS yang konsisten, maka semakin tinggi nilai konsistensi antara RKPD dan PPAS.

Untuk itu analisis dilakukan dengan menyandingkan dokumen RKPD dan PPAS, sehingga diperoleh tingkat konsistensi program maupun kegiatan bidang Perhubungan, Komunikasi dan Informatika antara RKPD dan PPAS Kabupaten Pegunungan Bintang tahu 2013-2015 menunjukkan bahwa dalam dokumen RKPD tahun 2013, 2014 dan 2015 telah disusun program-program yang akan dilaksanakan pada tahun bersangkutan. Program tersebut telah dilengkapi dengan rincian kegiatan beserta anggarannya.

Demikian juga dengan dokumen PPAS, program-program yang direncanakan telah disertai dengan kegiatan dan anggarannya. Dalam dokumen PPAS kegiatan telah disusun dengan target biaya pertahunnya. Pada dokumen PPAS tahun 2013 untuk program tingkat konsistensinya dengan RKPD adalah $66,67 \%$ termasuk dalam kategori baik, hal ini dapat dilihat pada tabel 1.1 di bawah ini.

Tabel 1.1. Analisa Tingkat Konsistensi Program Di Bidang Perhubungan, Komunikasi dan Informatika dalam RKPD dan PPAS Tahun 2013

\begin{tabular}{|c|c|c|c|l|c|c|}
\hline \multirow{2}{*}{ No } & \multicolumn{2}{|c|}{ Program } & \multicolumn{4}{c|}{ Penilaian Konsisten } \\
\cline { 2 - 7 } & Dokumen RKPD & Dokumen PPAS & \multicolumn{2}{c|}{ Deskripsi } & Jumlah & $\%$ \\
\hline 1 & 4 program & 4 Program & $\square$ & Konsisten & 4 & 66,67 \\
\hline 2 & 2 program & - & $\square$ & Tidak Konsisten I & 2 & 33,33 \\
\hline 3 & - & - & $\square$ & Tidak Konsisten II & - & - \\
\hline \multicolumn{3}{|c|}{ Jumlah } & 6 & 100,00 \\
\hline
\end{tabular}

Sumber : RKPD dan PPAS Dishubkominfo 2013 ( data di olah )

Tabel 1.2. Analisa Tingkat Konsistensi KegiatanDi Bidang Perhubungan, Komunikasi dan Informatika dalam RKPD dan PPAS Tahun 2013

\begin{tabular}{|c|c|c|c|l|c|c|}
\hline \multirow{2}{*}{ No } & \multicolumn{2}{|c|}{ Kegiatan } & \multicolumn{3}{c|}{ Penilaian Konsisten } \\
\cline { 2 - 7 } & $\begin{array}{c}\text { Dokumen } \\
\text { RKPD }\end{array}$ & $\begin{array}{c}\text { Dokumen } \\
\text { PPAS }\end{array}$ & \multicolumn{2}{|c|}{ Deskripsi } & Jumlah & $\%$ \\
\hline 1 & 18 kegiatan & 18 kegiatan & $\square$ & Konsisten & 18 & 27,27 \\
\hline 2 & 42 kegiatan & - & $\square$ & Tidak Konsisten I & 63,63 \\
\hline 3 & - & 6 kegiatan & $\square$ & Tidak Konsisten II & 6 & 9,09 \\
\hline \multicolumn{5}{|c|}{ Jumlah } \\
\hline
\end{tabular}

Sumber : RKPD dan PPAS Dishubkominfo, 2013 ( data di olah )

Tabel 1.2 dilihat bahwa tingkat Konsistensinya sebesar 27,27\% termasuk dalam kategori buruk dimana total anggaran di RKPD Rp 58.245.000.000, sedangkan di PPAS sebesar Rp. 10.725.827.500 ini berarti terjadi under estimate yang sangat rendah di PPAS sebesar Rp. 47.519.172.500 atau 33.91 \% dibawah dari yang ditargetkan dalam RKPD.

Dari hasil analisis konsistensi dari tahun 2013 menunjukkan bahawa dalam penyusunan program bidang perhubungan, komunikasi dan informatika pada 
PPAS sudah berpedoman pada RKPD. Sedangkan dalam penyusunan kegiatan, dapat dilihat bahwa penyusunan rencana kegiatan bidang perhubungan, komunikasi dan informatika pada PPAS masih ada yang tidak berpedoman pada RKPD sebanyak 6 (sembilan) kegiatan yaitu: (1) Pengawasan dan Pengembangan Jaringan Komunikasi dan Informasi; (2) Pembangunan Terminal Darat Oksibil; (3) Pengadaan Sarana Pemeliharaan Berupa Handy Mover; (4) Peningkatan Lapter Elpumek; (5) Perencanaan Lapter Korowai, Alemsom, Sekame, Pedam, Kirimu, Elpumek, Denom dan Apron Nongme; (6) Pengawasan Lapter Korowai, Alemsom, Sekame, Pedam ,Kirimu, Eipumek, Denom dan Apron Nongme.

Walaupun menunjukkan tingkat konsistensi yang baik karena berada pada rentang nilai 60,0 - 79,0. Namun masih saja terjadi penambahan kegiatan baru.

Tabel 1.3 Analisa Tingkat Konsistensi Program Di Bidang Perhubungan, Komunikasi dan Informatika dalam RKPD dan PPAS Tahun 2014

\begin{tabular}{|c|c|c|c|l|c|c|}
\hline \multirow{2}{*}{ No } & \multicolumn{2}{|c|}{ Program } & \multicolumn{3}{c|}{ Penilaian Konsisten } \\
\cline { 2 - 7 } & $\begin{array}{c}\text { Dokumen } \\
\text { RKPD }\end{array}$ & $\begin{array}{c}\text { Dokumen } \\
\text { PPAS }\end{array}$ & \multicolumn{2}{|c|}{ Deskripsi } & Jumlah & $\%$ \\
\hline 1 & 3 program & 3 Program & $\square$ & Konsisten & 3 & 75 \\
\hline 2 & 1 program & - & $\square$ & Tidak Konsisten I & 1 & 25 \\
\hline 3 & - & - & $\square$ & Tidak Konsisten II & - & - \\
\hline \multicolumn{5}{|c|}{ Jumlah } & 4 & 100,00 \\
\hline
\end{tabular}

Sumber : RKPD dan PPAS Dishubkominfo, 2014 ( data di olah )

Pada tabel 1.3 diatas untuk program bidang perhubungan, komunikasi dan informatika tahun 2014 tingkat konsistensinya adalah 75\% masuk dalam kategori baik.

Tabel 1.4 Analisa Tingkat Konsistensi KegiatanDi Bidang Perhubungan, Komunikasi dan Informatika dalam RKPD dan PPAS Tahun 2014

\begin{tabular}{|c|c|c|c|c|c|c|}
\hline \multirow{2}{*}{ No } & \multicolumn{2}{|c|}{ Kegiatan } & \multicolumn{4}{|c|}{ Penilaian Konsisten } \\
\hline & $\begin{array}{c}\text { Dokumen } \\
\text { RKPD }\end{array}$ & $\begin{array}{c}\text { Dokumen } \\
\text { PPAS }\end{array}$ & & Deskripsi & Jumlah & $\%$ \\
\hline 1 & 20 kegiatan & 20 kegiatan & $\square$ & Konsisten & 20 & 74,07 \\
\hline 2 & 4 kegiatan & - & $\square$ & Tidak Konsisten I & 4 & 14,81 \\
\hline 3 & - & 3 kegiatan & $\square$ & Tidak Konsisten II & 3 & 11,12 \\
\hline \multicolumn{5}{|c|}{ Jumlah } & 27 & 100,00 \\
\hline
\end{tabular}

Sumber : RKPD dan PPAS Dishubkominfo, 2014 (data di olah)

Pada Tabel 1.4 diatas dapat dilihat bahwa untuk kegiatan yang konsisten dengan RKPD adalah sebanyak 20 kegiatan atau 74,07\% sedangkan 4 kegiatan yang semula ada di RKPD namun dalam dokumen PPAS hilang atau tidak dimasukan. Adapula 3 ( tiga ) kegiatan yang semula tidak berada dalam dokumen RKPD namun masuk dalam dokumen PPAS.

Hal ini menunjukan bahwa penyusunan program bidang Perhubungan, Komunikasi dan Informatika tahun 2014 sudah sebagian besar memperhatikan 
dan mempedomani dokumen RKPD yang telah dibuat sebelumnya. Sedangkan dalam penyusunan kegiatan dapat dilihat bahwa penyusunan bidang Perhubungan, Komunikasi dan Informatika pada PPAS masih ada yang tidak berpedoman pada RKPD yaitu sebanyak 3 kegiatan yaitu: (1) Pembangunan Lapter Balamding; (2) Pengecoran Rabat Beton Terminal Penumpang Bandara Oksibil; (3) Studi Perencanaan Penanggulangan Longsor Run Way di Lapter Kiwirok.

Tabel 1.5 Analisa Tingkat Konsistensi Program Di Bidang Perhubungan, Komunikasi dan Informatika dalam RKPD dan PPAS Tahun 2015

\begin{tabular}{|c|c|c|c|l|c|c|}
\hline \multirow{2}{*}{ No } & \multicolumn{2}{|c|}{ Program } & \multicolumn{4}{c|}{ Penilaian Konsisten } \\
\cline { 2 - 7 } & $\begin{array}{c}\text { Dokumen } \\
\text { RKPD }\end{array}$ & $\begin{array}{c}\text { Dokumen } \\
\text { PPAS }\end{array}$ & \multicolumn{2}{|c|}{ Deskripsi } & Jumlah & $\%$ \\
\hline 1 & 3 program & 3 Program & $\square$ & Konsisten & 3 & 75 \\
\hline 2 & 1 program & - & $\square$ & Tidak Konsisten I & 1 & 25 \\
\hline 3 & - & - & $\square$ & Tidak Konsisten II & - & - \\
\hline \multicolumn{3}{|c|}{ Jumlah } & 4 & 100,00 \\
\hline
\end{tabular}

Sumber : RKPD dan PPAS Dishubkominfo, 2015 (data di olah )

Dari tabel 1.5 diatas hasil analisis konsistensi program pada dokumen RKPD dan PPAS tahun 2015 bidang perhubungan, komunikasi dan informatika adalah $75 \%$ yakni dari 4 ( empat) program di tahun 2015 terdapat 3 ( tiga ) program yang ada di dokumen RKPD dan dokumen PPAS dan termasuk dalam kategor baik.

Tabel 1.6 Analisa Tingkat Konsistensi KegiatanDi Bidang Perhubungan, Komunikasi dan Informatika dalam RKPD dan PPAS Tahun 2015

\begin{tabular}{|c|c|c|c|l|c|c|}
\hline \multirow{2}{*}{ No } & \multicolumn{2}{|c|}{ Kegiatan } & \multicolumn{3}{c|}{ Penilaian Konsisten } \\
\cline { 2 - 7 } & $\begin{array}{c}\text { Dokumen } \\
\text { RKPD }\end{array}$ & $\begin{array}{c}\text { Dokumen } \\
\text { PPAS }\end{array}$ & \multicolumn{2}{|c|}{ Deskripsi } & Jumlah & $\%$ \\
\hline 1 & 20 kegiatan & 20 kegiatan & $\square$ & Konsisten & 20 & 74,07 \\
\hline 2 & 4 kegiatan & - & $\square$ & Tidak Konsisten I & 4 & 14,81 \\
\hline 3 & - & 3 kegiatan & $\square$ & Tidak Konsisten II & 3 & 11,12 \\
\hline \multicolumn{3}{|c|}{ Jumlah } & 27 & 100,00 \\
\hline
\end{tabular}

Sumber : RKPD dan PPAS Dishubkominfo, 2015 (data di olah )

Sedangkan untuk kegiatan yang konsisten dengan RKPD adalah 74,07\% atau sebanyak 20 kegiatan.Terdapat 4 (empat) kegiatan yang ada di dokumen RKPD namun tidak berada pada dokumen PPAS ( tingkat inkonsistensi sebesar $14,81 \%$ ) dan 3 ( tiga ) kegiatan yang semula tidak ada dalam dokumen RKPD namun masuk dalam dokumen PPAS atau tingkat inkonsistensi sebesar 11, $12 \%$. Hal ini meunjukkan bahwa penyusunan anggaran di bidang perhubungan, komunikasi dan informatika tahun 2015 di Kabupaten Pegunungan Bintang tergolong baik, namun masih adanya pemahaman yang kurang antara legislatif dan eksekutif dalam menyusun atau membahas program maupun kegiatan yang akan dianggarkan pada PPAS harus masuk dulu di RKPD. 
Analisis antara PPAS dan APBD Bidang Perhubungan, Komunikasi dan Informatika Kabupaten Pegunungan Bintang tahun 2013-2015, Prioritas dan Plafon Anggaran Sementara (PPAS) merupakan program prioritas dan patokan batas maksimal anggaran yang diberikan kepada SKPD untuk setiap program sebagai acuan dalam penyusunan RKA-SKPD. PPAS yang telah disepakati oleh Pemerintah Daerah dan DPRD selanjutnya dijadikan pedoman dalam penyusunan Rencana Kerja dan Anggaran SKPD pada masing-masing SKPD.

RKA-SKPD dari seluruh dinas setelah dikompilasi akan disusun menjadi Raperda APBD, selanjutnya setelah pembahasan dan persetujuan DPRD akan ditetapkan menjadi Perda APBD setelah sebelumnya di evaluasi oleh Pemerintah Provinsi Papua, Anggaran Pendapatan dan Belanja Daerah (APBD) adalah rencana keuangan tahunan Pemerintah Daerah yang dibahas dan disetujui bersama oleh Pemerintah Daerah dan DPRD yang ditetapkan dengan Peraturan Daerah.

Analisis tingkat konsistensi program dan kegiatan antara PPAS dan APBD dimaksudkan untuk melihat bagaimana konsistensi APBD terhadap program dan kegiatan yang ada pada PPAS. Semakin banyak program dan kegiatan di APBD yang konsisten, maka semakin tinggi nilai konsistensi antara PPAS dan APBD.

Matrik konsolidasi dokumen PPAS dengan APBD Kabupaten Pegunungan Bintang tahun 2013-2015 yang disusun untuk melihat sejauh mana konsistensi program-program antara kedua dokumen tersebut.

Dalam dokumen APBD tahun 2013, 2014 dan 2015 telah disusun Programprogram yang akan dilaksanakan pada tahun bersangkutan. Program tersebut telah dilengkapi dengan rincian kegiatan beserta anggarannya hal ini dapat dilihat di lampiran 4.4, 4.5 dan 4.6. Pada tahun 2013 dari total 6 program yang terdapat dalam dokumen APBD 4 program yang konsisten dengan dokumen PPAS atau sebesar $66,67 \%$ berada dalam kategori baik. Ada 2 program yang semula tidak berada dalam dokumen PPAS namun masuk dalam dokumen APBD hal ini menunjukan ketidak konsistensi program sebesar 33,33\%, hal ini dapat dilihat pada tabel 1.7. di bawah ini.

Tabel 1.7 Analisa Tingkat Konsistensi Program Di Bidang Perhubungan, Komunikasi dan Informatika dalam PPAS dan APBD Tahun 2013

\begin{tabular}{|c|c|c|c|l|c|c|}
\hline \multirow{2}{*}{ No } & \multicolumn{2}{|c|}{ Program } & \multicolumn{4}{c|}{ Penilaian Konsisten } \\
\cline { 2 - 7 } & Dokumen PPAS & Dokumen APBD & \multicolumn{2}{c|}{ Deskripsi } & Jumlah & $\%$ \\
\hline 1 & 4 program & 4 Program & $\square$ & Konsisten & 4 & 66,67 \\
\hline 2 & - & 2 Program & $\square$ & Tidak Konsisten I & 2 & 33,33 \\
\hline 3 & - & - & $\square$ & Tidak Konsisten II & - & - \\
\hline \multicolumn{3}{|c|}{ Jumlah } & 6 & 100,00 \\
\hline
\end{tabular}

Sumber : PPAS dan APBD Tahun 2013 ( data di olah) 
Dalam penyusunan kegiatan bidang perhubungan, komunikasi dan informatika tahun 2013 tingkat konsistensi antar dokumen APBD terhadap dokumen PPAS sebesar 47,61\% masuk dalam kategori sedang, karena kegiatan-kegiatan yang disusun dalam APBD tahun 2013 sebanyak 20 ( dua puluh ) kegiatan ada dalam dokumen PPAS. 17 (tujuh belas) kegiatan dalam dokumen APBD tahun 2013 namun sebelumnya tidak masuk dalam dokumen PPAS 2013. 5 ( lima ) kegiatan yang sebelumnya ada dalam dokumen PPAS tahun 2013 namun tidak masuk dalam dokumen APBD, hal ini dapat dilihat pada table 1.8 di bawah ini.

Tabel 1.8 Analisa Tingkat Konsistensi KegiatanDi Bidang Perhubungan, Komunikasi dan Informatika dalam PPAS dan APBD Tahun 2013

\begin{tabular}{|c|c|c|c|c|c|c|}
\hline \multirow{2}{*}{ No } & \multicolumn{2}{|c|}{ Kegiatan } & \multicolumn{3}{c|}{ Penilaian Konsisten } \\
\cline { 2 - 7 } & $\begin{array}{c}\text { Dokumen } \\
\text { PPAS }\end{array}$ & $\begin{array}{c}\text { Dokumen } \\
\text { APBD }\end{array}$ & \multicolumn{2}{|c|}{ Deskripsi } & Jumlah & $\%$ \\
\hline 1 & 20 kegiatan & 20 kegiatan & $\square$ & Konsisten & 20 & 47,61 \\
\hline 2 & 5 kegiatan & - & $\square$ & Tidak Konsisten I & 5 & 11,90 \\
\hline 3 & - & 17 kegiatan & $\square$ & Tidak Konsisten II & 17 & 40,47 \\
\hline \multicolumn{4}{|c|}{ Jumlah } & 42 & 100,00 \\
\hline
\end{tabular}

Sumber : PPAS dan APBD Tahun 2013 ( data di olah )

Dari hasil analisis konsistensi tahun 2013 menunjukkan bahawa dalam penyusunan program bidang perhubungan, komunikasi dan informatika pada APBD sudah berpedoman pada PPAS. Namun terdapat penambahan beberapa program dan kegiatan di didokumen APBD yaitu:

1. Program Peningkatan Sarana dan Prasarana Aparatur

a. Pemeliharaan Rutin/Berkala Gedung Kantor

b. Pemeliharaan Rutin/Berkala Kendaraan Dinas/Operasional

2. Program Pelayanan Administrasi Perkantoran
a. Penyediaan Jasa Surat Menyurat
b. Penyediaan Jasa Komunikasi, Sumber Daya Air dan Listrik
c. Penyediaan Alat Tulis Kantor
d. Penyediaan Barang Cetakan, dan Penggandaan
e. Penyediaan Peralatan dan Perlengkapan Kantor
f. Penyediaan Makanan dan Minuman
g. Rapat-Rapat Kordinasi dan Konsultasi ke Luar Daerah
h. Kegiatan Pelayanan dan Penyelenggaran Pemerintah

3. Program Peningkatan Dsiplin Aparatur

a. Pengadaan Pakaian Dinas Beserta Perlengkapannya

Tingkat konsistensi Penyusunan program/kegiatan tahun 2013 berada pada level sedang ( 40,0 - 59,9), karena masih saja terjadi penambahan Program dan kegiatan baru pada dokumen APBD tahun 2013. 
Pada dokumen APBD tahun 2014 terdapat 3 program yang konsisten dengan dokumen PPAS tahun 2014 atau tingkat konsistensi sebesar 37,5\% termasuk dalam kategori buruk. 5 program tidak konsisten karena sebelumnya dalam dokumen PPAS tidak ada namun masuk dalam dokumen APBD tahun 2014 atau tingkat inkonsistensi sebesar $63,5 \%$, hal ini dapat dilihat pada tabel 1.9 berikut ini :

Tabel 1.9 Analisa Tingkat Konsistensi Program Di Bidang Perhubungan, Komunikasi dan Informatika dalam PPAS dan APBD Tahun 2014

\begin{tabular}{|c|c|c|c|l|c|c|}
\hline \multirow{2}{*}{ No } & \multicolumn{2}{|c|}{ Program } & \multicolumn{4}{c|}{ Penilaian Konsisten } \\
\cline { 2 - 7 } & $\begin{array}{c}\text { Dokumen } \\
\text { PPAS }\end{array}$ & $\begin{array}{c}\text { Dokumen } \\
\text { APBD }\end{array}$ & \multicolumn{2}{|c|}{ Deskripsi } & Jumlah & $\%$ \\
\hline 1 & 3 program & 3 Program & $\square$ & Konsisten & 3 & 37,5 \\
\hline 2 & - & 5 Program & $\square$ & Tidak Konsisten I & 5 & 62,5 \\
\hline 3 & - & - & $\square$ & Tidak Konsisten II & - & - \\
\hline \multicolumn{5}{|c|}{ Jumlah } & 8 & 100,00 \\
\hline
\end{tabular}

Sumber : PPAS dan APBD Tahun 2014 ( data di olah)

Pada dokumen APBD tahun 2014 terdapat 22 kegiatan yang konsisten dengan dokumen PPAS tahun 2014 atau tingkat konsistensi sebesar 59,45\% termasuk dalam kategori sedang. 14 kegiatan tidak konsisten karena sebelumnya dalam dokumen PPAS tidak ada namun masuk dalam dokumen APBD tahun 2014 atau tingkat inkonsistensi sebesar $37,84 \%$, hal ini dapat dilihat pada tabel 1.10 berikut ini :

Tabel 1.10 Analisa Tingkat Konsistensi KegiatanDi Bidang Perhubungan, Komunikasi dan Informatika dalam PPAS dan APBD Tahun 2014

\begin{tabular}{|c|c|c|c|l|c|c|}
\hline \multirow{2}{*}{ No } & \multicolumn{2}{|c|}{ Kegiatan } & \multicolumn{3}{c|}{ Penilaian Konsisten } \\
\cline { 2 - 7 } & $\begin{array}{c}\text { Dokumen } \\
\text { PPAS }\end{array}$ & $\begin{array}{c}\text { Dokumen } \\
\text { APBD }\end{array}$ & \multicolumn{2}{|c|}{ Deskripsi } & Jumlah & $\%$ \\
\hline 1 & 22 kegiatan & 22 kegiatan & $\square$ & Konsisten & 22 & 59,45 \\
\hline 2 & 1 kegiatan & - & $\square$ & Tidak Konsisten I & 1 & 2,70 \\
\hline 3 & - & 14 kegiatan & $\square$ & Tidak Konsisten II & 14 & 37,84 \\
\hline \multicolumn{5}{r}{ Jumlah } \\
\hline
\end{tabular}

Sumber : PPAS dan APBD Tahun 2014 ( data di olah )

Dari hasil analisis konsistensi dari tahun 2014 menunjukkan bahwa dalam penyusunan program bidang perhubungan, komunikasi dan informatika pada APBD sudah berpedoman pada PPAS. Namun terdapat penambahan beberapa program dan kegiatan di didokumen APBD yaitu:

1. Program Pembangunan Sarana dan Prasarana Perhubungan

a. Pembangunan Terminal Darat Tahap 1

b. Pembuatan Talud Bronjong, Penyiapan Lahan PembangunanTerminal Darat

2. Program Peningkatan Disiplin Aparatur 
a. Pengadaaan Pakaian Dinas Beserta Perlengkapan

3. Program Peningkatan Kapasitas Sumber Daya Aparatur

a. Peningkatan SDM Aparatur melalui diklat-diklat

4. Program Pelayanan Administrasi Perkantoran

a. Penyediaan Jasa Surat Menyurat

b. Penyediaan Barang cetakan dan Penggandaan

c. Penyediaan Peralatan dan Perlengkapan Kantor

d. Penyediaan Bahan Logistik Kantor

e. Penyediaan Bahan makanan dan minuman

f. Rapat-rapat Koordinasi dan Konsultasi ke Luar Daerah

g. kegiatan Pelayanan dan Penyelanggaraan Pemerintahan

5. Program Peningkatan Sarana dan Prasarana Aparatur

a. Pemeliharaan Rutin./Berkala Kendaraan Dinas/Operasional

b. Pemeliharaan Rutin/Berkala Gedung Kantor

Pada dokumen APBD tahun 2015 terdapat 7 program yang konsisten dengan dokumen PPAS tahun 2015 atau tingkat konsistensi sebesar 77,78\% termasuk dalam kategori baik. 2 program tidak konsisten karena sebelumnya dalam dokumen PPAS tidak ada namun masuk dalam dokumen APBD tahun 2015 atau tingkat inkonsistensi sebesar 22,22\%, hal ini dapat dilihat pada tabel 1.11 berikut ini :

Tabel 1.11 Analisa Tingkat Konsistensi Program Di Bidang Perhubungan, Komunikasi dan Informatika dalam PPAS dan APBD Tahun 2015

\begin{tabular}{|c|c|c|c|l|c|c|}
\hline \multirow{2}{*}{ No } & \multicolumn{3}{|c|}{ Program } & \multicolumn{3}{c|}{ Penilaian Konsisten } \\
\cline { 2 - 7 } & $\begin{array}{c}\text { Dokumen } \\
\text { PPAS }\end{array}$ & $\begin{array}{c}\text { Dokumen } \\
\text { APBD }\end{array}$ & \multicolumn{2}{|c|}{ Deskripsi } & Jumlah & $\%$ \\
\hline 1 & 7 program & 7 Program & $\square$ & Konsisten & 7 & 77,78 \\
\hline 2 & - & 2 Program & $\square$ & Tidak Konsisten I & 2 & 22,22 \\
\hline 3 & - & - & $\square$ & Tidak Konsisten II & - & - \\
\hline \multicolumn{5}{|c|}{ Jumlah } & 9 & 100,00 \\
\hline
\end{tabular}

Sumber : PPAS dan APBD Tahun 2015, (data di olah )

Dalam penyusunan dokumen APBD tahun 2014 terdapat 19 kegiatan yang konsisten dengan dokumen PPAS tahun 2014 atau tingkat konsistensi sebesar $63,33 \%$ termasuk dalam kategori baik. 11 kegiatan tidak konsisten karena sebelumnya dalam dokumen PPAS tidak ada namun masuk dalam dokumen APBD tahun 2014 atau tingkat inkonsistensi sebesar 36,37\%, hal ini dapat dilihat pada tabel 1.12 berikut ini : 
Tabel 1.12 Analisa Tingkat Konsistensi KegiatanDi Bidang Perhubungan, Komunikasi dan Informatika dalam PPAS dan APBD Tahun 2015

\begin{tabular}{|c|c|c|c|c|c|c|}
\hline \multirow{2}{*}{ No } & \multicolumn{2}{|c|}{ Kegiatan } & \multicolumn{3}{c|}{ Penilaian Konsisten } \\
\cline { 2 - 7 } & $\begin{array}{c}\text { Dokumen } \\
\text { PPAS }\end{array}$ & $\begin{array}{c}\text { Dokumen } \\
\text { APBD }\end{array}$ & \multicolumn{2}{|c|}{ Deskripsi } & Jumlah & $\%$ \\
\hline 1 & 19 kegiatan & 19 kegiatan & $\square$ & Konsisten & 19 & 63,33 \\
\hline 2 & - & 11 Kegiatan & $\square$ & Tidak Konsisten I & 11 & 36,37 \\
\hline 3 & - & - & $\square$ & Tidak Konsisten II & 30 & 100,00 \\
\hline \multicolumn{5}{|c|}{ Jumlah } \\
\hline
\end{tabular}

Sumber : PPAS dan APBD Tahun 2015, (data di olah )

Dari hasil analisis konsistensi dari tahun 2015 menunjukkan bahwa dalam penyusunan program/kegiatan bidang perhubungan, komunikasi dan informatika pada APBD sudah berpedoman pada PPAS. Namun terdapat penambahan beberapa program dan kegiatan di didokumen APBD yaitu:

1. Program Peningkatan Sarana dan Prasarana Aparatur
a. Pemelilharaan Rutin/Berkala Kendaraan Dinas/Operasional
b. Pemeliharaan Rutin/Berkala Gedung Kantor

2. Program Pengembangan Komunikasi, Informasi dan Media Massa
a. Pengadaaan Alat Komunikasi berupa SSB dan GPS
b. Pengadaan Saranna Informasi berupa Televisi, Parabola Receiver dan Catut daya

3. Program Pelayanan Adminitrasi Perkantoran
a. Penyediaan Jasa Surat Menyurat
b. Penyediaan Barang cetakan dan Penggandaan
c. Penyediaan Peralatan dan Perlengkapan Kantor
d. Penyediaan Bahan Logistik Kantor
e. Penyediaan Bahan makanan dan minuman
f. Rapat-rapat Koordinasi dan Konsultasi ke Luar Daerah
g. kegiatan Pelayanan dan Penyelanggaraan Pemerintahan
h.

Faktor-Faktor yang mempengaruhi Ketidakonsistenan Perencanaan dan Penganggaran Dari pembahasan analisis konsistensi perencanaan dan 
penganggaran di atas, maka dapat diketahui penyebab ketidakkonsistensi antara dokumen perencanaan dan penganggaran, yaitu :

a Kurangnya komitmen dalam pelaksanaan RPJMD dan RKPD,

b Belum maksimalnya kinerja tim anggaran daerah baik eksekutif maupun legislatif.

c Kualitas RENSTRA yang disusun oleh SKPD kurang memadai.

d Intervensi DPRD yang terlalu kuat : Anggota DPRD sering mengusulkan kegiatan baru pada saat rapat PanitiaKhusus (Pansus), yang mana kegiatan itu tidak tercantum di dalam dokumen perencanaan yang sebelumnya sehingga menyimpang dari program dan kegiatan yang diusulkan oleh SKPD.

e Kurangnya informasi dan koordinasi dengan kementerian/lembaga tingkat pusat tentang program/kegiatan yang akan dilaksanakan di daerah sehingga menyebabkan usulan program/kegiatan dapat berubah.

\section{KESIMPULAN DAN SARAN}

\section{Kesimpulan}

Dilihat dari konsistensi dokumen perencanaan dan dokumen penganggaran (RKPD dan PPAS) Dinas Perhubungan, Komunikasi dan Informatika Pegunungan Bintang cukup berhasil dengan kategori baik. Demikian juga halnya bila dilihat konsistensi program (PPAS dan APBD) yang kategori sedang untuk tahun 2013-2014 dan kategori baik untuk tahun 2015. Namun, konsistensi kegiatan untuk tiga tahun yang di analisis masuk dalam kategori buruk.

Faktor-faktor yang sering mempengaruhi kualitas dan konsistensi perencanaan dan penganggaran, program dan kegiatan adalah komitmen dalam pelaksanaan RPJMD dan RKPD, kinerja tim anggaran, kualitas RENSTRA.

\section{Saran}

Meningkatkan pemahaman dan kompetensi tim anggaran eksekutif dan legislatif. Melakukan sosialisasi, regulasi dan monitoring yang mengharuskan komitmen eksekutif dan legislatif untuk menjamin integrasi antar dokumen perencanaan dan penganggaran. Peningkatan intensitas informasi dan komunikasi dengan Pemerintah Pusat maupun Pemerintah Provinsi. 


\section{DAFTAR PUSTAKA}

Ata, Diana Novita. 2015. Analisis Konsistensi Perencanaan dan Penganggaran Bidang Pendidikan di Kabupaten Sumba Timur (Pada Dinas Pendidikan, Pemuda dan Olah Raga. Jakarta : Universitas Terbuka

Dickey, Terry. 2004. Dasar-Dasar Penganggaran. (Irma Andriani R). Jakarta: PPM.

Khusaini, Moh. 2006. Ekonomi Publik: Desentralisasi Fiskal dan Pembangunan Daerah.Malang: BPFE UB.

Khusaini, Moh. 2009. The Analysis of Consistency of Planning and Budgeting (Study of SomeDistricts and Cities in Indonesia). Malang: FEB UB.

Koncoro, Mudrajat. 2004. Otonomi dan Pembangunan Daerah. Penerbir Erlangga: Jakarta

Mangkoesoebroto, Guritno. 2008. Ekonomi Publik Edisi ke-3. Yogyakarta: BPFE Yogyakarta.

Mardiasmo. 2002. Otonomi dan Manajemen Keuangan Daerah. Yogyakarta: Andi.

Meldayeni. 2011. Analisis Konsistensi Perencanaan dan Penganggaran Bidang Kesehatan diKota Solok Tahun 2007-2010. Tesis dipublikasikan. Padang: Program PascasarjanaUniversitas Andalas.

Muluk, Khairul. 2007. Desentralisasi dan Pemerintahan Daerah. Malang: Bayumedia dan Centerfor Indonesian Reform.

Octaviani, Rini. 2008. Analisis Konsistensi Perencanaan dan Penganggaran Program Pendidikan dasar dan menengah di Kabupaten Solok Selatan. Tesis Program Pascasarjana Universitas Andalas.

Peraturan Menteri Dalam Negeri Nomor 13 Tahun 2006 jo Permendagri Nomor 59 Tahun 2007tentang Pedoman Pengelolaan Keuangan Daerah.

Peraturan Menteri Dalam Negeri Nomor 54 Tahun 2010 tentang Pelaksanaan PeraturanPemerintah Nomor 8 Tahun 2008.

Peraturan Pemerintah Republik Indonesia Nomor 8 Tahun 2008 tentang Tahapan, Tata CaraPenyusunan, Pengendalian dan Evaluasi Pelaksanaan Rencana Pembangunan Daerah.

Prasetya, Ferry. 2012. Modul Ekonomi Publik V: Teori Pengeluaran Pemerintah. FEUB.Malang.

Suhadak dan Nugroho, Trilaksono. 2007. Paradigma Baru Pengelolaan Keuangan Daerahdalam Penyusunan APBD di Era Otonomi. Malang: Bayumedia dan Lembaga Penerbitan\& Dokumentasi FIA-Unibraw.

Wahyuningsih, Rutiana. 2007. Resposibility Kebijakan Perncanaan dan Penganggaran Daerah. LGSP 
Jurnal Keuda Vol. 2 No. 2

ISSN 2477-7838

Undang-Undang Nomor 25 Tahun 2004 tentang Sistem Perencanaan Pembangunan Nasional.

Undang-Undang Nomor 23 Tahun 2014 tentang Pemerintahan Daerah.

Yandra, Febie. 2011. Analisis Perencanaan dan Penganggaran pada Dinas Pekerjaan UmumKabupaten Solok Tahun 2006-2010.

Oxford Learner's Pocket Dictionary. Oxford University Press. 